Reports of the Progress of Applied Chemistry Issued by the Society of Chemical Industry. Vol. 22. Pp. 818. (London : Society of Chemical Industry, 1937.) n.p.

$\mathrm{T}$ HIS annual volume fully maintains the high standard which chemists and chemical manufacturers have learned to expect. It is presented in the traditional form of sectional reviews on the principal branches of applied chemistry, fully documented by reference to the relevant technical literature and patent specifications, and to abstracts thereof published by the Bureau of Chemical and Physiological Abstracts. The series is therefore almost indispensable to anyone taking an active interest either in the progress of chemistry or in the advancement of any branch of industry which involves the use of chemical operations, a knowledge of the chemical composition or behaviour of materials, or the employment of chemists for control or research. Further, it is a convenient guide-book in the hands of those who wish merely to take a bird's-eye view of modern technology in its chemical aspects.

The present issue deals, inter alia, with fuels, with dyes and textiles; with paper, glass, cement, steel, drugs, oils, paints, rubber, leather, sugar, and soil ; with foods and water; with electrochemistry and photography. Explosives, which are treated biennially, do not appear in this volume. The section dealing with bleaching, dyeing, printing, and finishing has this year been incorporated with that on fibres, textiles, and cellulose, the combined chapter occupying between eighty and ninety pages.

Name and subject indexes are provided.

$$
\text { A. A. E. }
$$

Fermente, Hormone, Vitamine :

und die Beziehungen dieser Wirkstoffe zueinander. Von Dr. Robert Ammon und Dr. Wilhelm Dirscherl. Pp. xvi+451. (Leipzig : S. Hirzel, 1938.) 30 gold marks.

H. ULER has classified the hormones and vitamins together as "ergones", and has laid stress on the fact that ergones may act as coferments. The best examples are vitamins $B_{1}$ and $B_{2}$, which are important parts of the molecules of cocarboxylase and Warburg's yellow ferment. It seems probable that many ergones may act by influencing enzymes. The authors of the present book class together as "ergines" all the organic substances which act in small doses-enzymes, hormones and vitamins. These groups interact in many ways and are conveniently considered together.

The book is written from the point of view of the biochemist, but clinical observations are also discussed. Authorities are not quoted with full references; but the author's name and the year are usually mentioned, and there should be no serious difficulty in tracing the originals. The book contains much information and is usually fairly accurate, but uncritical. The vasodilator substances which are found in tissue extracts are included as Gewebshormone. The work of Rowntree and his collaborators on the thymus is not mentioned.

\section{Land of Ice and Fire}

By Hans Wilhelmsson Ahlmann. Pp. xiii $+271+16$ plates. (London: Kegan Paul and Co., Ltd., 1938.) 12s. 6d. net.

THE Vatna Jökull of Iceland, with an area of well over three thousand square miles, is larger than any other glacier in Europe. It is rugged, crevassed and even chaotic in parts, and is associated with an undue share of fog, wind, snow and rain. The heavy precipitation and the extensive ablation make it an area of important investigation into the relations between the growth and wastage of glaciers. From time to time it has been crossed, notably in 1932, when the Cambridge expedition, which is not mentioned in this book, made a double traverse.

Prof. Ahlmann's Swedo-Icelandic expedition of 1936 was designed to penetrate the eastern interior of the ice sheet, chiefly in order to measure growth and wastage. This entailed the digging of pits in which the thickness of each year's accretion could be seen and the planting of surface posts against which wastage could be noted. It is not an easy area in which to travel, and in Prof. Ahlmann's book the task loses nothing of its reputation for difficulty, but there were some fine days and on the whole the expedition achieved its aims, though this book does little more than touch on the conclusions.

However, the work of the expedition was not confined to Vatna Jökull. Several other parts of Iceland were visited, and there is much of interest in the account of peasant life in Iceland and the struggle with adverse soil and climate that Icelandic agriculture and stock raising have to face. These chapters give a good picture of modern Iceland. It is a pity that the translation from the Swedish is somewhat laboured and in places lacking in idiomatic English usage. The photographic illustrations are excellent, and the map, though rather meagre, serves its purpose.

R. N. R. B.

\section{The Dissection and Study of the Sheep's Brain:} as an Introduction to the Study of the Human Brain. By James Wilkie. (Oxford Medical Publications.) Pp. xvi+95. (London : Oxford University Press, 1937.) 6s. net.

7 HE object of this little work, as stated in the preface by the author, who is attached to the department of biology at Guy's Hospital Medical School, is "to enable the student of comparative anatomy to use the text books of human anatomy; and to help the medical student who wishes to improve his knowledge of the anatomy of the brain, or to begin the study of the human brain with a certain background of comparative anatomy".

The book is divided into five chapters, devoted respectively to removal of the brain, its general anatomy, the first dissection in which a general study is made of the cerebral hemispheres, cerebellum and brain stem, the second dissection, and hand sections.

The text is liberally interspersed with diagrams of the human brain as well as that of the sheep, and is provided with a full index. 